\title{
ASEAN Political-Security Community: Challenges of establishing regional security in the Southeast Asia
}

\author{
Bama Andika Putra \\ Department of International Relations, Universitas Hasanuddin \\ Indonesia \\ bama@unbas.ac.id \\ Darwis \\ Department of International Relations, Universitas Hasanuddin \\ Indonesia \\ darwis.hi@unhas.ac.id \\ Burhanuddin \\ Department of International Relations, Universitas Hasanuddin \\ Indonesia \\ boerbi76@gmail.com
}

Abstract. The paper determines the essence and the functionality of the ASEAN Political-Security Community (APSC) by looking at a wide range of regional studies, evaluating theoretical approaches in international relations, and examining case studies related on regional security in the Southeast Asia, since the establishment of the APSC in 2015. Essential complex challenges faced include the rise of China, unresolved territorial conflicts and maritime disputes, rigid application of non-interference principles in the internal affairs of the local states, and the failure of ASEAN in protecting human rights regionwide. Based on the study cases that were analysed in this paper, the paper concludes that: (1) the essence of multilateralism is challenged by the complicated nature of interstate relationships and interactions of individual ASEAN member states; (2) development of security cooperation cannot be measured due to complexity of geopolitical and geoeconomic interests; and (3) boundaries in the ASEAN framework have very weak foundations. The developments taking place in the region have hampered ASEAN's ability to optimally perform its core purpose of establishing a stable political environment in the region.

Keywords: ASEAN, regional security, international organizations, Southeast Asia, regionalism.

JEL Classification: F51, F53. 


\section{INTRODUCTION}

During the last 50 years international relations worldwide have undergone many changes in both theoretical approaches and actual practices of various actors. The terrifying events of the World War II have caused radical change in how states view international relations today. From a power-hungry and materially-focused realist framework, countries have come to embracing the possibility for multilateral cooperation.

The emergence of inter-governmental institutions allowed the states to form contracts that bind them under various agreements covering such aspects as political stability, economic interdependence, globalization, social justice, and more. In the Southeast Asian region, the Association of South East Asian Nations (ASEAN) has been the first institution to facilitate multilateral negotiations, promote regional identity, and ensure sustainable peace among its member countries.

Establishment of the ASEAN Political-Security Community is regarded as a significant achievement in promoting and preserving peace in the Southeast Asian region. However, it has also been criticized for its inability to resolve the long history of territorial conflicts among the individual members of this community. The APSC has been in a constant struggle to balance its role on the protection of inter-state relations against the protection of the entire Southeast Asian populace, especially in what concerns human rights. It faces an increasingly complicated relationship with other world powers such as the United States of America, Russia, and China which is intensified by the unpredictable alliances formed between these powerful countries and some of the ASEAN members. Due to the extent of problems and complexities faced by the ASEAN Political-Security Community coupled with the absence of a firm ASEAN Secretariat, it would be appropriate to consider the APSC as a failed attempt in maintaining regional peace and security.

This article is based on analytical-descriptive research methodology. Given the nature of the subject, the required information was collected through library and Internet research. The information compiled is the accumulation of case studies utilized to analyse the challenges of ASEAN in establishing regional order, since the establishment of the APSC in 2015. Furthermore, the required data were extracted from books and articles and analysed through a mixture of qualitative and quantitative means of analysis.

The objective of the paper is to analyse how several key international political dynamics in Southeast Asia and surrounding areas have equally contributed towards the challenges of ASEAN in establishing solid regional security in the Southeast Asia. The authors highlight the relationships of the study cases with the general aim of the APSC in establishing regional order. Currently, there is an absence of a comprehensive study on the effectiveness of the ASEAN Political-Security Community in terms of promoting regional peace, securing political stability, protecting human rights, and developing a shared regional norm. The results of the research on challenges for the APSC will be of significant help in formulation of future policies for the Southeast Asian region. This study hopes to contribute to the development of more effective and legitimate regional institutions that appropriately respond to the political security needs of the member countries.

\section{BUILDING THE ASEAN POLITICAL SECURITY COMMUNITY}

The Association of Southeast Asian Nations was first established on August 8, 1967, through the ASEAN Declaration that was signed by the first five member states namely Malaysia, Singapore, Indonesia, Philippines, and Thailand. It was explicit in the ASEAN Declaration that there is a need for meaningful cooperation among the Southeast Asian nations to attain peace, freedom, social justice, and well-being (Severino, 2008). It is among the primary aims and purposes of the Association of Southeast Asian Nations to promote 'regional peace and stability through abiding respect for justice and the rule of law in the relationship among countries of the region.' According to the Treaty of Amity and Cooperation in Southeast 
Asia (Lee, 2011), the principles to be upheld by all member countries of the ASEAN include the effective cooperation among each other, renunciation of the threat or use of force, peaceful settlement of disputes, mutual respect for national identity and sovereignty, and non-interference in the internal affairs of one another.

The formation of international institutions and regional organizations such as the ASEAN can be examined using various analytical frameworks that provide different theoretical foundations and assertions that are necessary for the comprehensive understanding of the processes, policies, conflicts, and actions of the institutions and its individual members. It is critical to explore International Relations based on different sets of perspectives. We should not grant a privileged position to theories, and neglect other theories.

For the realists and neo-realists, the absence of a supreme world government and the presence of power-hungry states cause the inherent anarchical nature of the international political realm. World War II and the Cold War which happened prior to the formation of ASEAN have only intensified the validity of the realists' assertion on the presence of a 'vicious circle of security and power accumulation' of countries (Herz, 1950). The post-war climate has ultimately brought the state to the center of international relations and regarded the security dilemma as a never-ending condition (Brown \& Ainsley, 2005).

However, political thinkers, key international players, and national authorities, later on, started to embrace the possibility of managing anarchy and the persistent security dilemma through pluralistic ideologies that consider the interdependence of states and the role of non-state actors in forming the behavior of countries (Keohane \& Nye, 2011). Norms and identity building under the constructivist framework emerged as key concepts in the modification of state behavior and the promotion of international cooperation. By recognizing the ability of Southeast Asian nations to be united by their common regional identity, the institution has decided to adopt the overarching theme of having an ASEAN Way.

The traumatic events of the past world war paved the way for the emergence of the 'security communities' as a concept to be reckoned with. This challenged the dominance of the realist thought because it opened possibilities for the cooperation of nations in accordance with established norms and a shared identity. Security community refers to groups of states which have developed a long-term habit of peaceful interaction and ruled out the use of force in settling disputes with other members of the group (Acharya, 2009).

It is because of the acceptance of the concept of security communities that the ASEAN included the establishment of the ASEAN Political-Security Community (APSC) in 2015. The APSC basically forms part of the Three Pillars of the Association along with the ASEAN Economic Community and the ASEAN Socio-Cultural Community. The APSC is characterized by three key features which include being 'a rulesbased community of shared values and norms; a cohesive, peaceful, stable, and resilient region with shared responsibility for comprehensive security; and a dynamic and outward-looking region in an increasingly integrated and interdependent world (ASEAN, 2009).

The Community operates using clear roadmap with corresponding plans and timeframes through the APSC Blueprint. Despite the promising features of the APSC Blueprint, its effectiveness continues to be challenged by traditional security issues, national political problems, intra-state discords, transnational crimes, terrorism, drug trafficking, developmental gaps, and economic struggles, among others (Nesadurai, 2017). The attainment of regional peace and stability is anchored on the ability of the ASEAN PoliticalSecurity Community to attain shared values, norms, and principles. Norms are 'standards of behavior defined in terms of rights and obligations' (Kratochwil, 1991) with a primary function of prescribing and proscribing behaviour (Crawford, 2002). Apart from regulating behavior, norms also have a constitutive factor which teaches states about new interests and new identities (Checkel, 1998). However, to determine if the APSC has truly achieved its goal of identity formation could be extremely difficult because collective 
identity is hardly a quantifiable concept. Academic theorists do not have an agreed set of parameters to assert if a group of states has truly developed a shared norm, a 'we feeling,' or collective identity. However, there are three indicators to help establish the presence of collective identity. These indicators are a commitment to multilateralism, development of security cooperation, and the constitution of boundaries and membership.

Progress can be difficult to gauge with the absence of clear and quantifiable goals for the ASEAN Political-Security Community. In order to establish respect among the ASEAN population for a common identity, it is of foremost importance to define collective identity despite the differences in national identity and the diversity of each ASEAN member state.

\section{UNPREDICTABLE ALLIANCES WITH HEGEMONIC STATES}

The period of ASEAN's establishment was characterized by the emergence of other powerful countries aside from Russia and the USA. Two of the fastest growing countries, China and India, have caused relational changes in the international political and economic realm most especially in the Southeast Asian region. This development during the formative years of ASEAN has caused political theorists to doubt the sustainability of ASEAN as a regional organization that is capable of keeping peace among its member states. An international political community that is multipolar in nature could cause complexity in interstate relations and chaos in security conditions. Neo-realists argue that multipolar systems are more prone to developing war because of unpredictable patterns of state alliances and interactions (Acharya, 2013).

Some Western political theorists assert that there are striking parallels to the events prior to World War II and the multipolar system occurring in the Southeast Asian region today. It is feared that the horrific events in Europe during the late 19th and early 20th Centuries could potentially happen to Asia.

Despite the negative impression of a multipolar order in the region, there are still some scholars who regard such arrangement as beneficial to the maintenance of peace and security in Southeast Asia. The great powers are considered to play a significant role in the management of international order (Bull, 1977). Having a multipolar order in the region can prevent conflict by increasing state interaction and promoting pluralistic common interests (Acharya, 2004). Wars may be less likely to happen because potential aggressors could be barred from accurately evaluating its alliances, alignments, and coalitions (K. W. Deutsch \& Singer, 1964).

After more than five decades of existence, the Association of Southeast Asian Nations remains to be functioning and continues to grow its influence in the region and in the international political system. It has played a significant role in reducing interstate conflicts and even managed to involve the great powers in its own regional affairs peacefully. As Acharya (2015) points out, the current ASEAN order shall not be described according to the Eurocentric term of multipolarity but must be characterized by the idea of multiplexity. A multiplex world considers the influence of different players. It is constrained neither by great powers alone nor the sovereign states. Having a multiplex system recognizes the role of international institutions, non-governmental organizations, multinational corporations, and traditional networks in the creation of order. It no longer validates the ability of a particular hegemon to rule the entire international political realm. A multiplex world promotes shared leadership and pluralistic goals at the global and regional levels.

Indeed, the current actions of the ASEAN align with Acharya's assertion of a multiplex order. The ASEAN consistently involves other great powers such as the USA, China, Japan, South Korea, India, Australia, Russia, and the European Union in building an international security strategy. By refusing to allow the concentration of powers between China and the USA, the ASEAN effectively splits the dominant influences into other great powers such as Russia and Japan. These external states have a pivotal role in the 
maintenance of intra-regional security yet also maintains the absence of coercive diplomacy arising from any of the great powers.

Despite the efforts made by the ASEAN to balance the influence of great powers, its individual members craft their own diplomatic relations according to their economic needs and developmental requirements. Individual states display randomness in their behavior concerning their relationship with the great powers. Thailand, Myanmar, and Vietnam continually show fascination with interacting with the United States of America, China, India, and Japan to receive economic aid that is necessary for their national development. The Philippines has also recently changed its course on foreign relations when President Rodrigo Duterte assumed leadership in 2016. From a long history of solid ties with the US, the Philippines now starts to surprisingly embrace cooperation with China even in the aspect of coastguard collaboration.

Despite the acknowledged importance of maintaining intra-regional security, it is also necessary to ensure that the relationship of the entire ASEAN goes well with other major powers in order to prevent any potential conflicts (Kihl, 1989). Interactions between and among extra-regional players shall be appropriately aligned with the ideals of the ASEAN Political-Security Community in order to sustain lasting peace and cooperation.

The need for stability outside of the Southeast Asian region is made implicit in the move of the ASEAN to support East Asian regionalism through the East Asian Community and in its decision to include other Western powers in the ASEAN Regional Forum (ARF) and the Asia-Pacific Economic Cooperation (APEC). All these extra-regional associations and interactions are considered as a move by the ASEAN to use its strategic position to balance major powers and protect regional security (Goh, 2007).

In 2016, the ASEAN invited Russia to take an active role in the security architecture of the entire AsiaPacific region. Russia's inclusion points to the ASEAN's desire to prevent the negative effects of China's increasing eminence as a superpower in Asia. This act of containing the possible aggression from an ultimately powerful China may be called as an 'institutional self-binding' arrangement which restrains the great power's actions in order protect its own political and economic interests (Ikenberry, 1998). Intensifying East Asian regionalism also offers another form of 'institutional balancing' against the dominance of the United States of America in Asia. 'Institutional balancing' is different from the traditional balance of power concept because the restraining agent in this scenario is an institution such as the ASEAN against a great power such as the US. The establishment of the East Asian Summit is a lucrative attempt of the ASEAN to facilitate interaction among the powerful emerging states such as China, Japan, and India. However, the ASEAN leadership in the East Asian Community is questioned particularly because of the institution's internal difficulties and the individual member states' domestic political problems. Furthermore, the ASEAN stance does not translate to individual members' interaction with East Asian and Western powers. Southeast Asian countries still remain to prioritize their own national interests over the ASEAN goals.

\section{CHINA'S SUPREMACY}

\subsection{ASEAN's Silence in Disputed Territories}

Article 13 of the 1976 Treaty of Amity and Cooperation in Southeast Asia stipulates that 'the High Contracting Parties shall have the determination and good faith to prevent disputes from arising.' Abiding by the principles of international law and implementing inter-state cooperation contribute to the preservation of regional stability. Maritime boundary issues and territorial disputes will definitely not be resolved without the willingness of every contending party to compromise with each other and to respect international arbitration. 
Inter-State land and maritime territorial boundary disputes in Southeast Asia since 2000

\begin{tabular}{|l|l|}
\hline Territory & Claimants \\
\hline Natuna Islands & Indonesia, China \\
\hline Sipadan and Ligitan Islands & Indonesia, Malaysia \\
\hline Scarborough Shoal & Philippines, China \\
\hline Spratly Islands & Vietnam, China \\
\hline Ambalat & Indonesia, Malaysia \\
\hline Preah Vihear Temple Area & Cambodia, Thailand \\
\hline Paracel Islands & Vietnam, China \\
\hline
\end{tabular}

Source: compiled by the authors

The silence of ASEAN in regards to inter-state land and maritime territorial boundary disputes involving states in Southeast Asia are clearly shown in table 1. Since the establishment of the ASEAN and the APSC, ASEAN embraces a problematic stance of non-interference in all disputes and conflicts occurring in Southeast Asia. The position has led ASEAN unable to establish regional order in Southeast Asia in both the spheres of conflict management and conflict resolution. Individual state members have taken the leading role in managing most of the conflict that has occurred, except for territorial disputes involving the People's Republic of China.

One of the greatest hurdles in achieving a functional security community is the jurisdictional contest on the South China Sea. The South China Sea measures around 1.16 million square miles and surrounded by different countries including the Philippines, China, Taiwan, Malaysia, Vietnam, Brunei, and Singapore. The strategic location of the South China Sea has valuable significance in the political security of each claimant state. Apart from being territorially advantageous for military defense and offense, the disputed maritime area also has a potential for increasing the natural gas resources of the countries (Lajčiak, 2017). It is estimated by the United States Energy Information Administration that there are around 11 billion barrels of oil and 190 trillion cubic feet of natural gas that lies in the seabed of the South China Sea (Majumdar, 2013). It also serves as a major link for the economic trade of the countries in the Pacific, Europe, and the Middle East.

The establishment of the Association of Southeast Asian Nations and the other regional communities following it has been positively seen as beneficial to resolving conflicts and managing tensions related to the territorial dispute. By conducting regional forums, informal discussions, and multilateral negotiations, regional violence is effectively avoided (Yu, 2016). In 2002, the ASEAN and the People's Republic of China had even mutually issued a Declaration on the Conduct of Parties in the South China Sea. In this document, all parties 'reaffirm their commitment to the purposes and principles of the Charter of the United Nations, the 1982 UN Convention on the Law of the Sea, the Treaty of Amity and Cooperation in Southeast Asia, the Five Principles of Peaceful Coexistence, and other universally recognized principles of international law which shall serve as the basic norms governing state-to-state relations.' They also expressed commitment to building trust and confidence among each other by exercising self-restraint in the conduct of activities relating to the dispute.

In spite of the presence of such multilateral documents and agreements, China has consistently been seen to show disregard for them. It has pursued its territorial expansion and military buildup in the contested territories. China has been regarded as the strongest among all claimants in terms of military prowess. For decades, the Chinese forces have been active in occupying some of the islands located at the South China 
Sea in order to modernize the territory for military purposes. In 1974, China showed aggression by evicting Vietnamese troops in the Paracel Islands through the People's Liberation Army \& Navy (Simon, 2012).

In 2014, China suddenly released a claim that the waters of the Natuna Islands belong to their Republic with their official passports surprisingly including such areas. Historically, the Natuna Islands have been the issue of territorial contention only between Indonesia and Vietnam (Robertua \& Sinaga, 2018). The marine area of the Natuna is part of the Riau Islands in Indonesia just along the southern part of the Strait of Malacca. Because of this unpredictable move of China, the Indonesian authority intensified its defense mechanism in the province covering the Natuna waters. Indonesia's National Defense Forces have been deployed in the area to anticipate the possibility of China's infiltration (Aplianta, 2015). Currently, tension progresses among Southeast Asian nations and China with regard to the constant aggressive movement of the Chinese government in claiming territories and exclusive maritime jurisdiction at the South China Sea or the West Philippine Sea.

In 2013, the Philippines brought the issue of the South China Sea dispute to the International Arbitral Tribunal through the issuance of the state's Notification and Statement of Claim. The document basically challenges China's claims on portions of the South China Sea in view of the provisions stated under the 1982 United Nations Convention on the Law of the Sea (UNCLOS) of which both China and the Philippines are signatories. It argues that China has encroached on the rights of the Philippines to its exclusive economic zone and continental shelf. It has asserted multiple points on China's violation of the UNCLOS such as the establishment of certain structures on submerged banks, Chinese forces' interference on Philippine security measures in the area, the occupation of uninhabitable coral projections, and other unlawful acts (Santamaria, 2018).

In the same year, the People's Republic of China responded by sending a Note Verbal to the Philippines stating its position that China has indisputable sovereignty over the Nanhai Islands and its adjacent waters. The government of China encourages the Philippines to continue their bilateral negotiations and resume the Confidence Building Measures Mechanisms between the two countries. China further asserts that the Arbitral Tribunal lacks jurisdiction on the South China Sea case. China has recently been strengthening its position in the South China Sea dispute by working on various methods such as the expansion of its construction activities in the disputed reefs and islands, improvement of its scientific and technological apparatus in the area, and the reinforcement of its sovereignty through various propaganda.

China also improves its own case by working on a strategic relationship with the ASEAN and its individual members. It continually offers economic aid and grants to ASEAN countries such as Cambodia and Laos to push for the continued implementation of the Declaration of Conduct of Parties in the South China Sea (Thao, 2003) which could create pressure on the part of the Philippines to resume bilateral negotiations with China. Some foreign relations analysts also assert that even Brunei's silence on the South China Sea dispute has been bought by China. From being highly vocal on its objections to China's growing presence in the disputed islands, Brunei has suddenly become quiet with its claims. The Asia Times has discovered that Chinese investments in Brunei now total to more than $\$ 6$ Billion and have helped improve the country's economic status, oil refinery, and national infrastructure (Jacques, 2018).

Ultimately, China has shown an aggressive stance on its claim by successfully setting up its paramilitary forces and strictly enforcing its own maritime laws in the disputed. Despite being a signatory to the Declaration on the Conduct of Parties in the South China Sea, China still continues to violate the provisions stipulated in the declaration such as inhabiting previously uninhabited reefs, shoals, and islands. The unprecedented growth of military activities and infrastructure developments in the area are also a cause of concern for the entire Southeast Asian region. However, ASEAN does not offer an assertive solution to protect the interests of its member states. Discussions concerning the South China Sea dispute are even 
constantly denied in the agenda of the ASEAN Regional Forum (ARF) because of strong objections by China and other ASEAN member countries.

\subsection{China's Growing Influence on Southeast Asian Countries}

Great power politics offers a highly pessimistic view on the rise of a particular state's political, military, and economic power (Clowes \& Choroś-Mrozowska, 2015). It is argued that an emerging powerful state has a tendency to seek regional hegemony due to its need for expansion and survival. Based on this assumption, the growth of China's power can be considered as a fearful circumstance in the security of the entire Asia Pacific and Southeast Asian region. Despite China's inclusion in the East Asian Community which is headed by the ASEAN, it has consistently been observed to be moving towards a bilateral approach among individual member states of the region. By consistently applying a bilateral strategy in its diplomatic relations, China also seems to be disregarding the essence of the ASEAN as a regional institution. This action results in a division among Southeast Asian countries most especially in issues relating to territorial disputes. China continues to negotiate terms and conditions with other claimant countries on certain disputed territories. The history of China's bilateral negotiations concerning the Spratly's Islands has been consistently going well with Malaysia and Brunei while going at odds with the Philippines and Vietnam. This, however, has suddenly changed with the increasing alliance between the Philippines and China.

It is expected that China will behave in such a way because ASEAN remains to have no legitimate bargaining power over the regional institution. In terms of defense spending and military assets, China still exceeds those of the combined member states' military resources. In 2016, China has a recorded $\$ 146$ Billion total defense budget. This figure has a glaring difference when compared to the $\$ 39.7$ Billion defense spending of all Southeast Asian countries in 2015 (Rosyidin, 2016).

International relations scholars regard China as the greatest challenge to the ASEAN. The economic capabilities and military prowess of China are exceedingly incomparable to all the resources of the Southeast Asian nations. Some analysts assert that ASEAN could only either bandwagon with China or balance against it. Both of these analyses seem to be unfavorable to the security conditions in the region. If ASEAN decides to bandwagon with China, it will create an acceptance on the hegemonic influence of China over the regional institution. Also, if ASEAN resorts to making alliances with other powerful states in order to balance against China, it will only jeopardize its efforts to create a cooperative community in the entire East Asian region (Acharya, 2009).

Southeast Asian nations general maintain a positive relationship with China for economic development, investment promotion, industrial trade expansion, and tourism (Dapice, 2015). The relationship of individual ASEAN states with China can be classified into four different types. The first is the game type which is characterized by heavy cooperation and competition. The second is a complementary type with high cooperation and low competition as key features. The third type is the flight type which exhibits low cooperation and high competition. The fourth type is a loose relationship which is characterized by low cooperation and low competition. But the influence of China on individual member states of ASEAN are clearly highlighted in the 'Belt and Road Initiative,' involving states in Asia, Europe, and Africa (Bruce-Lockhart, 2017). The economic interdependence in the current status quo is vastly concerning, considering the volume of two-way trades between Southeast Asian states and China. With the addition of the initiative, the economic interdependence will evolve to the level in which investments and trades determined by the global economic superpower of China. As shown in Figure 1 below, the scope of the Belt and Road Initiative occupies key and strategic chokepoints of Asia, Europe, and Africa. 


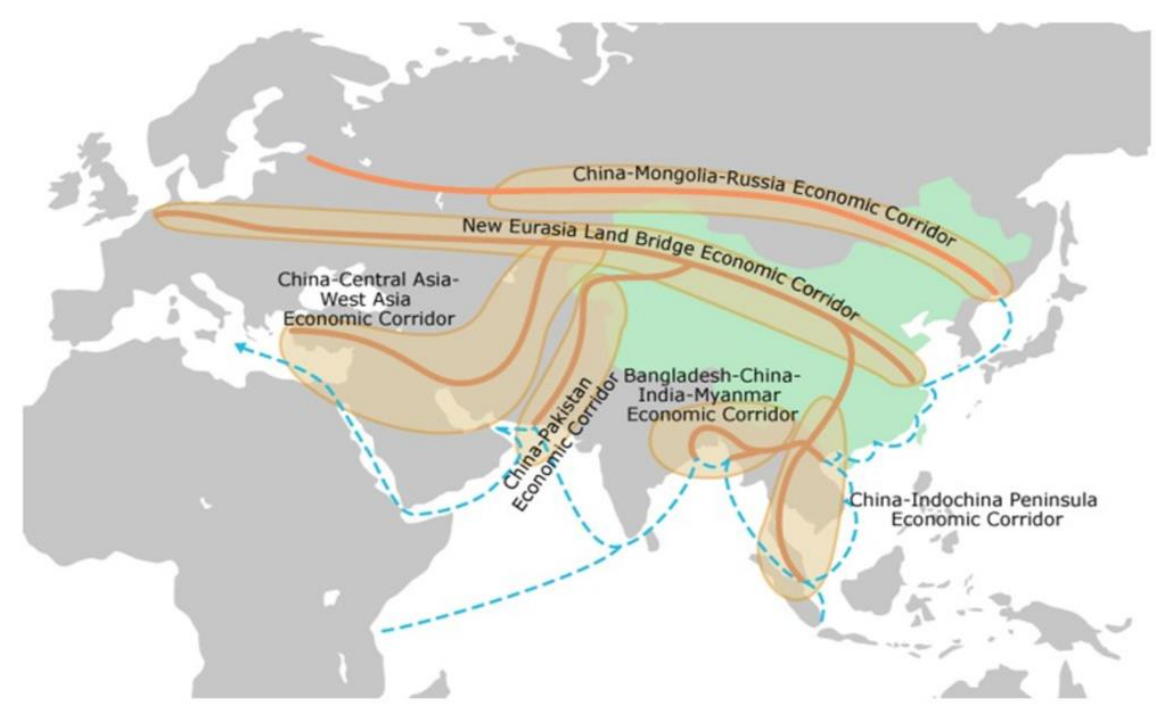

Figure 1. The Belt and Road Initiative: Six Economic Corridors Spanning Asia, Europe, and Africa

Source: World Economic Forum (2017)

Some scholars see that the Southeast Asian region is now becoming very weak because of the increasing influence of China among member states. It is even asserted that the very problem of ASEAN's institutional weakening stems from its expansion of membership to include Cambodia and Laos which are both strongholds of China. Recent national political changes have also created surprising changes in East Asian alliances whereby Malaysia, Thailand, and the Philippines are starting to accept alliances with the Chinese government in various aspects of governance (Dibb, 2017).

\section{FEAR ASSOCIATED WITH EVERY STATE'S INCREASING DEFENSE SPENDING}

Security communities are basically characterized by the 'absence of a competitive military buildup or arms racing involving their members (Acharya, 2009).' These communities remain to act in a pluralistic manner without undermining their members' national sovereignty. Also, states that belong to security communities refuse to engage in war and potential military conflicts despite the presence of opposing views on certain matters (K. Deutsch, 1988). The existence of security communities can be ultimately judged by the absence of such advanced preparations for large-scale violence between any two territories.

If we are to determine the success of the ASEAN Political-Security Community in terms of the absence or presence of preparations for a possible war, then we may judge ASEAN in the negative light. Over the years, we have seen a remarkable increase in the defense spending of individual ASEAN members. According to the study made by the Stockholm International Peace Research Institute (SIPRI) in 2014, the countries in Southeast Asia have made a significant increase in their military spending. Some of the member states have even reached an increase of more than $50 \%$ in the defense budget and expenditures in a span of four years (Abuza, 2015).

In 2014, Brunei was recorded to have spent 528 million USD in their military defense. It has seen a slow and steady increase of approximately 35\% from 2010-2014. Thailand spent around 5730 million USD in their military assets in 2014, with only around 15\% upward increase in the previous four years. Cambodia only allocated around 278 million USD in their 2014 annual budget for defense, but such value is a significant increase of 56.2\% from its 2010 spending. Indonesia spent 7020 million USD in 2014, a little bit 
less than what it spent in 2013 but definitely greater when compared with 2010 spending. The percentage change in Indonesia's military spending from 2010 to 2014 is around 50.6\%. The Philippines was recorded to have spent 3292 million USD in 2014, increasing only around 30\% from its 2010 defense budget. Vietnam has shown the greatest need and desire for military spending over four years from 2010 to 2014 by increasing its spending to more than $56 \%$, reaching the 4251 million USD mark.

Compared with all other Southeast Asian nations, Singapore is considered to be the wealthiest in military capabilities measured in terms of defense spending. Its records from 2010 to 2014 show a steady increase in military spending. In 2014 alone, it already spent 9841 million USD for defense. What is very surprising with all the figures above is the unpredictability of arms spending in relation to a country's total population or land area. Although Singapore is categorically small in terms of size, it shows a magnificently empowered military capability. Meanwhile, Indonesia still lags behind other ASEAN countries in terms of military spending despite its great population and land area.

This scenario is considered by some scholars as a good indication of the balancing that happens in the region. Although there is a noticeable increase in military spending of these countries, there still remains considerable stability in the region. The analysis of the importance of increased state defense spending shall not rest on mere figures alone. The underlying causes for the increase or decrease in military budgets and arms purchase shall also be examined in order to rightfully assess the significance of figures in the regional security arena. National authorities design their own defense programs and plans according to perceived international threats, domestic political instabilities, and geographical protection issues, among others.

Some analysists consider the increasing sophistication of ASEAN states' military assets as a necessary result of China's growing presence in the region. Since most member states of the ASEAN have a persisting conflict with China, they also exert their own efforts to build military capabilities as a protective measure from uncertain diplomatic affairs. Furthermore, there has been an evident increase in military spending of Southeast Asian nations because weapons, arms, and military paraphernalia have been easily accessible and widely available right after the Cold War Era. Arms manufacturers from around the globe have targeted other markets right after the Western countries have reduced their need for arms procurement. The prices of military equipment and tools have been offered at significantly cheaper rates. Seeing the opportunity of building a nation's military prowess and upgrading its levels to modern degrees at extensively decreased prices, these Southeast Asian nations have grabbed it which then caused the increase in military spending.

The authors came to a conclusion that the rise of defense budgets among ASEAN states are based on the volatile security environment of Southeast Asia in recent years. As seen in Figure 2, with consistent growth of military spendings, member states have indicated that the rise of China in the region is primarily that cause of the public policy changes (Zero Hedge, 2016). Though distance in comparison to the defense expenditures of global superpowers, the upward trend indicates an alarming orientation of the Southeast Asian regional dynamics. 


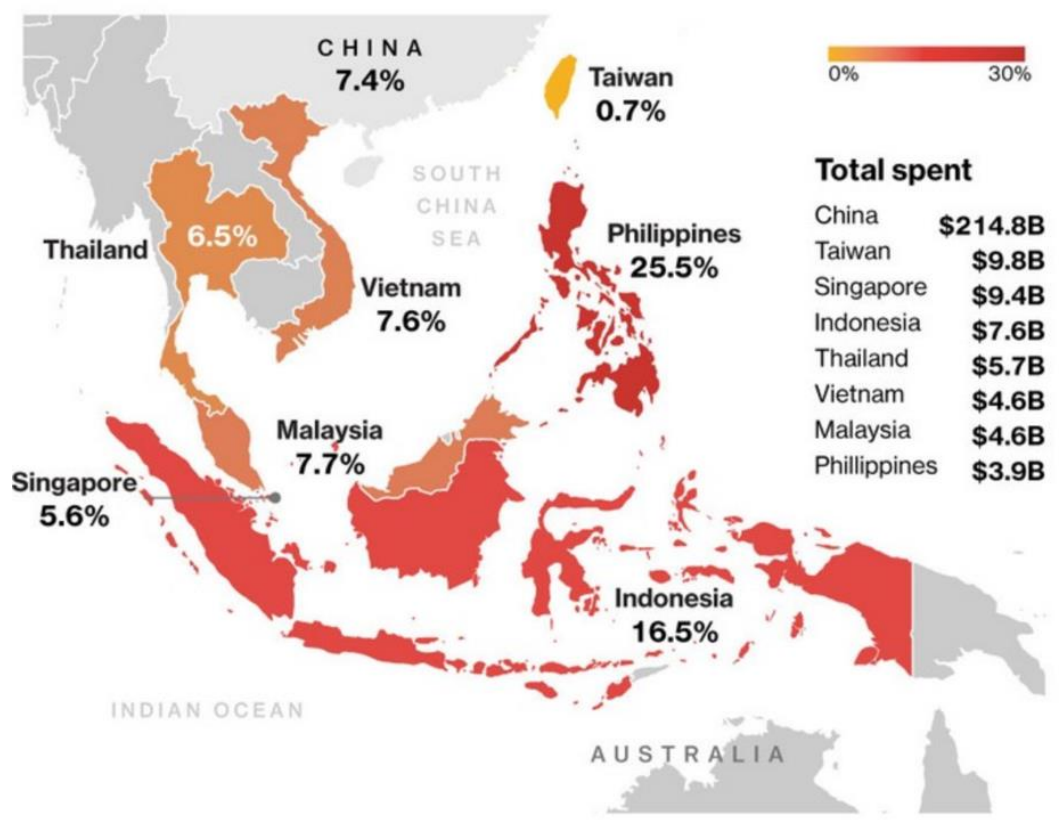

Figure 2. The rise of military spending of Southeast Asia, in reaction to China's aggressive claims in the South China Sea

Source: Zero Hedge (2016)

\section{HUMAN RIGHTS PROTECTION VERSUS STATE SOVEREIGNITY}

The ASEAN is anchored on the foundation of non-interference on the affairs of the state. This very concept of state sovereignty and liberty from regional coercion have caused a negative perception on the effectiveness of the ASEAN to contain, prevent, and correct the misconduct of its individual members in the aspect of human rights. Since APSC is characteristic of a peaceful region with shared responsibility for comprehensive security, it also necessarily entails the protection of human rights. A positive development in the way the ASEAN handles issues concerning the violation of basic human rights came in 2009 during the creation of the ASEAN Intergovernmental Commission on Human Rights (Ryu \& Ortuoste, 2014). This is considered as notable progress in the institution since it has finally touched on a very sensitive issue that most states would not like to be meddled with by external entities. It has been a symbolic achievement when it is breaking inter-state boundaries, furthering cooperation, and setting normative expectations in the regional political security community.

The ASEAN Intergovernmental Commission on Human Rights has given validation to the role of civil societies in protecting the rights of every individual from every country in the region. The AICHR has been given the duty to develop strategies that would protect human rights, to raise public awareness on its very concept, to obtain information from member states on data about human rights promotion and protection, and to promote the implementation of the institution's instruments for the protection of human rights, among others.

Since its inception, the Commission has already released a couple of promulgations including the ASEAN Human Rights Declaration. The declaration asserts the right of all people from each ASEAN member to a multitude of aspects such as the right to life, right to development, right to education, right to peace, and more. Along these rights, the member states are also given the primary responsibility to protect these rights by continuing friendship and cooperation for the attainment of regional stability and harmony (Davies, 2014). 
Although the establishment of the AICHR can be theoretically seen as a supreme achievement in the entire regional institution, there are points for criticism particularly in its effectiveness to combat stateinduced violation on their own citizens' rights. The ASEAN Intergovernmental Commission on Human Rights has also been doubted in its ability to properly perform its responsibilities given the very restrictions imposed by the commission upon itself. Explicit in its creation is the responsibility of the commission to promote human rights within the regional context but still to offer mutual respect to the distinct culture of its member states (Ryu \& Ortuoste, 2014). By considering regional particularities and cultural relativism in the promotion of human rights, critics and firm advocates are wary of how AICHR would handle human rights abuses that perpetually happen just because of their acceptability in certain cultures.

Article 2 of the Terms of Reference of the ASEAN Intergovernmental Commission on Human Rights further stipulates the principle of state sovereignty and independence. This basic principle serves as an ultimate barrier in the effectiveness of the AICHR as a regional institution that combats extra-judicial killings, police brutality, and other related violence. Looking at the technical aspect of the commission, it is also easy to see that it is quite as useless as a piece of paper for only being designated as a consultative body without any mechanism and authority to sanction states for any crime, violence, or circumstance related to the abuse of the rights of its people. The AICHR has no authority to receive complaints regarding the issue, and it also has no legitimacy to conduct investigations related to it.

Since the establishment of the AICHR in 2009, there had been numerous human rights violations with the individual member states as the primary agent. The Rohingya Crisis is one of the most haunting pictures of the inability of the ASEAN to protect human rights in the region. It has even been labeled by the United Nations as one of the world's largest and fastest growing refugee crises and a major humanitarian emergency (2017). The Rohingya Crisis has a history that can be traced back to a couple of centuries of historical and political development in Myanmar. In 1982 when a new citizenship law was promulgated in the country, the Rohingya people have been officially designated as stateless since they were not included in the list of 135 ethnic groups in the country. In 2012, violence flared in the Rakhine region of Myanmar where the Rohingya people reside. The violence caused by religious strife have caused the death of more than 200 people and the loss of homes of more than 150,000 Rohingyans. From the period of 2012 to 2015, it has been estimated that over a hundred thousand people from the Rohingya populace flee to Malaysia.

The year 2016 marked the beginning of a more intensified struggle between the government of Myanmar and the people of Rohingya. The border posts of the Rakhine State was attacked by more or less 300 Rohingya people who caused the death of 9 national police officers. This attack was said to be the start of Myanmar's intense crackdown of the Rohingya insurgent group that is called the Arakan Rohingya Salvation Army (ARSA). Myanmar's military implemented its clearance operations by burning down some Rohingya villages which caused the exodus of more than 600,000 Rohingya refugees in Bangladesh. Other records also show that the military killed even the innocent civilians and raped women during their crackdown.

Despite the alarming rate of people who were killed during the crackdown and during the process of fleeing from Myanmar, the ASEAN has seemingly kept a blind eye and a mute approach on the issue. In 2017 during the International Conference on Rohingya, the silence has been broken by Malaysian Prime Minister Najib Razak by addressing the issue in front of the entire ASEAN institution. He asserted that the refugee crisis, ethnic cleansing, and genocide that is happening in Myanmar is very disappointing and unacceptable (Petcharamesree, 2016).

The action of the Malaysian Prime Minister can be seen as a positive change in the ASEAN members' silence on atrocities committed by neighboring Southeast Asian countries. However, Malaysia's being critical on the human rights violations happening in other countries have no significant effect when there is no concerted effort from the entire regional institution. The ASEAN still upholds the principle of state 
sovereignty and non-interference even when the human rights violations are already on unprecedented scales.

There are still no positive developments on the status of the Rohingya Crisis even when the International Criminal Court has issued a decision in August 2018 stating that the Myanmar government is highly culpable for the activities that caused over 500,000 Rohingya Muslims to flee from their country going to Bangladesh. As indicated in table 2, the number of refugees and internally displaced persons due to the crisis in Myanmar, have led many to flee in neighbouring countries in South Asia and Southeast Asia. Since the 1970s, the figures have not receded, as the crisis has continued to prevail (Al-Jazeera, 2017). The Myanmar government firmly asserts that the ICC case is meritless and should, therefore, be dismissed. ASEAN has definitely failed to effectively respond to an emergency situation in the region such as the Rohingya crisis that has left hundreds of thousands of Southeast Asian people homeless, hungry, sick, and violated. Instead of being the primary multilateral institution in this crisis, it was actually the Western supranational and international organizations that have intervened in order to correct the wrongs of the Myanmar government towards its people. EU nations, the USA, UK, and even China have all done their part in providing crisis mediation and refugee assistance (Jati, 2017).

Table 2

Amount of Refugees and Internally Displaced Persons of Rohingya Muslims in Myanmar since the late 1970s, due to widespread persecutions

\begin{tabular}{|c|c|}
\hline Destination Countries & Estimation of Individuals \\
\hline Saudi Arabia & 200,000 \\
\hline United Arab Emirates & 10,000 \\
\hline Pakistan & 350,000 \\
\hline Bangladesh & 500,000 \\
\hline India & 14,000 \\
\hline Thailand & 5,000 \\
\hline Malaysia & 150,000 \\
\hline Myanmar (Internally Displaced Persons) & $\mathbf{1 , 0 0 0 , 0 0 0}$ \\
\hline
\end{tabular}

Source: Al-Jazeera (2017)

Among the recent dilemmas in ensuring human rights protection in the region is the ongoing war against illegal drugs of President Rodrigo Duterte in the Philippines. His campaign rhetoric in 2016 revolved around the promise of eliminating all kinds of illegal drug activities in the country. This active, aggressive, and seemingly effective stance against illegal drugs has received popular support among Filipino citizens. Since his assumption into office in 2016 until the end of 2017, there has already been more than 7,000 recorded deaths that are all related to the anti-drug war of the President (Bautista, 2017). Arguing in defense for his aggressive action on taking down all drug syndicates and individual drug pushers, he utters, "Crime against humanity? In the first place, I'd like to be frank with you: are they humans? What is your definition of a human being (Duterte, 2016)?" He even follows this line of reasoning in his other public appearances and official statements by claiming that he is more concerned about the safety and lives of the majority of the Filipino populace. In his most recent State of the Nation Address delivered in July of 2018, he gained popular approval when he claimed that his presidency is definitely more concerned about human lives rather than human rights (Duterte, 2018).

President Duterte even challenged the ASEAN as a regional institution by stating that the Philippines does not need cooperation with the ASEAN just a month after his assumption into office. The way that he 
deals with the ASEAN is strikingly different from the previous administrations that have offered great effort in building the regional institution (Heydarian, 2017). It is very disturbing how the ASEAN and even its individual member states remain silent on the issues concerning extra-judicial killings under the Duterte administration. At the 31st ASEAN Summit, it was Canadian Prime Minister Justin Trudeau who addressed human rights issues under the light of the war on drugs (Simangan, 2018). The absence of ASEAN is even made starker by the clear presence of the United Nations in the sphere of human rights protection in this particular country. The UN High Commissioner for Human Rights, Prince Prince Zeid Ra'ad Al Hussein has asked the international authorities to investigate the alleged violations under the Duterte rule (Bautista, 2017).

The ASEAN has faced a lot of criticism for its deafening silence on a number of human rights violations committed by its individual member states. Phelim Kine, the deputy director for Human Rights Watch in Asia, has asserted the failure of the ASEAN Intergovernmental Commission on Human Rights to curtail the abuses of the Southeast Asian authorities on their own citizens. According to him, there even exists a de facto code of silence specifically on the issue of human rights in the region particularly because of ASEAN's high regard on the preservation of the doctrine of non-interference in the affairs of individual states (Davies, 2013). It is argued that 'the salience of the doctrine of non-interference in Southeast Asia has long predated ASEAN (Acharya, 2009).' By upholding the principle of state sovereignty and the doctrine of non-interference, the ASEAN has failed to protect the citizens who were supposed to accept the collective concept of the ASEAN way.

\section{CONCLUSION}

The establishment of the Association of Southeast Asian Nations in 1967, a few years after the bloody events of World War II, is an affirmation of the constructivist thought that regional organizations have the capability to set norms in the international realm and influence the behavior of individual states. Its continued existence and constant development throughout the years also prove to be an accomplishment in international relations.

However, the ASEAN has also consistently faced criticisms and constantly experienced failures for its inability to completely realize an acceptable and sustainable condition of peace and stability in the entire region. Even the very establishment of the ASEAN Political-Security Community is questioned for its failure to fully organize a rules-based community of shared values and norms where all members of the region take part in maintaining a cohesive, peaceful, stable, and resilient international environment. The promising features of the APSC which are explicit in its Blueprint have failed to materialize and continue to experience struggles.

Key indicators in ascertaining the success of security communities are multilateralism, development of security cooperation, and the constitution of boundaries and membership. A glimpse at these indicators could confirm the existence of a security community in Southeast Asia. However, a deeper examination of the depth and quality of these indicators could prove otherwise.

First, the very essence of multilateralism is challenged by the complicated nature of inter-state relationships and the various ways that individual member states interact with great powers such as China, USA, Japan, and Russia. The initial stronghold of the United States of America in some Southeast Asian countries are definitely undeniable. However, the rise of China in recent years have drastically changed the way that Southeast Asian countries form their alliances. A lot of scholars assert that the increasing power of China in terms of political influence, economic resources, and military capability serves as an ultimate threat to the region's peace and stability. Individual countries conduct their own diplomatic relations with China according to their own interests and with utter disregard for the ASEAN way. Bilateralism continually 
characterizes the nature of relationships and negotiations between individual countries both from the Southeast Asian region and other parts of the international community.

Second, the development of security cooperation cannot be appropriately measured because of existing conflicts of interests concerning the geopolitical and geo-economic spheres. The increase in defense spending among individual countries, most especially those who are involved in territorial disputes, can be considered as a frightful phenomenon that underpins the theory of an existing regional arms race. China's growing military presence at the South China Sea causes the furtherance of the security dilemma that is felt in the region. Even human rights violations cannot receive a harmoniously active response from the ASEAN despite the evident struggles of the marginalized sectors in countries such as Myanmar and the Philippines. Extrajudicial killing and genocide remain to be undiscussed in the various multilateral negotiations, summits, and fora that are hosted by the Association of Southeast Asian Nations.

Third, the constitution of boundaries and membership in the ASEAN framework may have a beautifully designed façade yet with very weak foundations. Determination and respect for geographical boundaries of the region are still among the major problems faced by the institution. The South China Sea dispute continue to destroy the health of inter-state relationships and prevent the realization of the ASEAN Way. The ASEAN Secretariat also continues to fail in establishing its authority and legitimacy in the region. Because the regional institution is heavily anchored on individual state sovereignty and on the doctrine of non-interference in the internal affairs of the state, the ASEAN continue to remain as a consultative body with no power to discipline its members.

Although the ASEAN Political-Security Community can be considered to still be at its early years of development and that there are still more opportunities for growth, the difficulties that it currently experiences and the way that it reacts to such challenges only create a shaky ground for institutional strengthening. With a weak ASEAN Secretariat, a domineering Chinese power, self-interested states that form unpredictable alliances with great powers, pervasive human rights abuses, and unresolved territorial conflicts, the future of ASEAN Political-Security Community remains to be hazy. There is still a long, winding, and slippery road that needs to be traversed for the realization of its goals to achieve a shared norm for the maintenance of peace and stability in the region.

\section{REFERENCES}

Abuza, Z. (2015). Analyzing Southeast Asia's Military Expenditures. Retrieved April 13, 2018, from https://www.cogitasia.com/analyzing-southeast-asias-military-expenditures/

Acharya, A. (2004). Regional Security Arrangements in a Multipolar World? The European Union in Global Perspective. Berlin: Friedrich Ebert Stiftung.

Acharya, A. (2009). Constructing a security community in Southeast Asia: ASEAN and the problem of regional order: Second edition. New York: Routledge.

Acharya, A. (2013). ADBI Working Paper Series ASE AN 2030: Challenges of Building a Mature Political and Security Community Asian Development Bank Institute. Kasumigaseki.

Acharya, A. (2015). Doomed by Dialogue? Will ASEAN Survive Great Power Rivalry in Asia. Retrieved June 11, 2018, from http://www.theasanforum.org/doomed-by-dialogue-will-asean-survive-great-power-rivalry-in-asia/

Al-Jazeera. (2017). UN to Probe Alleged Crimes Against Rohingya in Myanmar. Retrieved October 16, 2018, from https://www.aljazeera.com/news/2017/03/probe-alleged-crimes-Rohingya-Myanmar-170324113526685.html

Aplianta, D. (2015). Indonesia's Response in the South China Sea Disputes: A Comparative Analysis of the Soeharto and the Post-Soeharto Era. Journal of ASEAN Studies, 3(1), 1-21. https://doi.org/https://doi.org/10.21512/jas.v3i1.749

ASEAN. (2009). ASEAN Political-Security Community Blueprint. Jakarta: ASEAN Secretariat. Retrieved from http://asean.org/wp-content/uploads/archive/5187-18.pdf

Bautista, L. B. (2017). Duterte and his quixotic war on drugs. Wollongong. Retrieved from 
https://www.hrw.org/news/2016/08/22/philippine-police-killing-spree-demands-

Brown, C., \& Ainsley, K. (2005). Understanding International Relations: Third Edition. Book. New York: Palgrave Macmillan. Bull, H. (1977). Does Order Exist in World Politics? The Anarchical Society- A Study of Order in World Politics. New York: Colombia University Press.

Bruce-Lockhart, Anna. (2017). China's \$900 Billion New Silk Road. What You Need to Know. Retrieved From https://www.weforum.org/agenda/2017/06/china-new-silk-road-explainer/

Checkel, J. T. (1998). The Constructive Turn in International Relations Theory. World Politics, 50(02), 324-348. https://doi.org/10.1017/S0043887100008133

Clowes, D., \& Choroś-Mrozowska, D. (2015). Aspects of Global Security - The Measurement of Power \&amp; its projection Results from Twenty Selected Countries (2000-2013). Journal of International Studies, 8(1), 53-66. https://doi.org/10.14254/2071-8330.2015/8-1/5

Crawford, N. C. (2002). Argument and Change in World Politics. Cambridge: Cambridge University Press. https://doi.org/10.1017/CBO9780511491306

Dapice, D. (2015). Economic Development in Southeast Asia. Economies, 3(3), $147-147$. https://doi.org/10.3390/economies3030147

Davies, M. (2013). The ASEAN Synthesis: Human rights, Non-intervention, and the ASEAN Human Rights Declaration. Georgetown Journal of International Affairs, 14(2), 51-58. https://doi.org/10.2307/43134411

Davies, M. (2014). An Agreement to Disagree: The ASEAN Human Rights Declaration and the Absence of Regional Identity in Southeast Asia. Journal of Current Southeast Asian Affairs, 33(3), 107-129. Retrieved from www.gigajournal-family.org

Deutsch, K. (1988). The Analysis of International Relations. New Jersey: Prentice Hall.

Deutsch, K. W., \& Singer, J. D. (1964). Multipolar Power Systems and International Stability. World Politics, 16(03), 390-406. https://doi.org/10.2307/2009578

Dibb, P. (2017). Why Southeast Asia and ASEAN are a Strategic Problem. Retrieved February 28, 2018, from http://www.eastasiaforum.org/2017/07/28/why-southeast-asia-and-asean-are-a-strategic-problem/

Duterte, R. (2016). State of the Nation Address 27 August 2016. Manila.

Duterte, R. (2018). State of the Nation Address 23 July 2018. Manila.

Goh, E. (2007). Great Powers and Hierarchical Order in Southeast Asia: Analyzing Regional Security Strategies. International Security, 32, 113-157. https://doi.org/10.2307/30130520

Herz, J. H. (1950). Idealist Internationalism and the Security Dilemma. World Politics, 2(2), 157-180.

Heydarian, R. J. (2017). Tragedy of Small Power Politics: Duterte and the Shifting Sands of Philippine Foreign Policy. Asian Security, 13(3), 220-236. https://doi.org/10.1080/14799855.2017.1354569

Ikenberry, G. J. (1998). Institutions, Strategic Restraint, and the Persistence of American Postwar Order. International Security, 23(3), 43. https://doi.org/10.2307/2539338

Jacques, J. (2018). China Has Bought Brunei’s Silence in South China Sea Dispute. Retrieved March 20, 2018, from https://www.thetrumpet.com/16927-china-has-bought-bruneis-silence-in-south-china-sea-dispute

Jati, I. (2017). Comparative Study of the Roles of ASEAN and the Organization of Islamic Cooperation in Responding to the Rohingya Crisis. IKAT: The Indonesian Journal of Southeast Asian Studies, 1(1), 17. https://doi.org/10.22146/ikat.v1i1.27466

Keohane, R., \& Nye, J. (2011). Power Eamp; Interdependence. Pearson Education. Boston: Pearson Education.

Kihl, Y. W. (1989). Intra-Regional Conflict and the Asean Peace Process. International Journal, 44(3), 598. https://doi.org/10.2307/40202616

Kratochwil, F. V. (1991). Rules, Norms, and Decisions: On the Conditions of Practical and Legal Reasoning in International Relations and Domestic Affairs. New York: Cambridge University Press.

Lajčiak, M. (2017). China's cultural fundamentals behind current foreign policy views: Heritage of old thinking habits in Chinese modern thoughts. Journal of International Studies, 10(2), 9-27. https://doi.org/10.14254/2071$8330.2017 / 10-2 / 1$

Lee, Y. Y. (2011). ASEAN Matters! Reflecting on the Association of Southeast Asian Nations. Singapore: National University of Singapore. https://doi.org/10.1142/8022

Majumdar, M. (2013). India's stakes in the South China Sea. International Journal of Humanities and Social Science (Vol. 3). 
Retrieved from http://www.economist.com/blogs/banyan/2012/03/south-china-sea

Nesadurai, H. E. S. (2017). ASEAN during the life of The Pacific Review : a balance sheet on regional governance and community building. The Pacific Review, 30(6), 938-951. https://doi.org/10.1080/09512748.2017.1304436

Petcharamesree, S. (2016). ASEAN and its approach to forced migration issues. The International Journal of Human Rights, 20(2), 173-190. https://doi.org/10.1080/13642987.2015.1079021

Robertua, V., \& Sinaga, O. (2018). Indonesia in the South China Sea Dispute: Humble-Hard Power. Jurnal Global \& Strategis, 11(2), 73. https://doi.org/10.20473/jgs.11.2.2017.73-83

Rosyidin, M. (2016). ASEAN and Russia: Creating a New Security Architecture | The Diplomat. Retrieved May 4, 2018, from https://thediplomat.com/2016/06/asean-and-russia-creating-a-new-security-architecture/

Ryu, Y., \& Ortuoste, M. (2014). Democratization, regional integration, and human rights: the case of the ASEAN intergovernmental commission on human rights. The Pacific Review, 27(3), 357-382. https://doi.org/10.1080/09512748.2014.909521

Santamaria, C. (2018). Sino-Philippine Joint Development in the South China Sea: Is Political Will Enough? Asian Politics \& Policy, 10(2), 322-340. https://doi.org/10.1111/aspp.12397

Severino, R. (2008). ASEAN. Singapore: Institute of Southeast Asian Studies.

Simangan, D. (2018). Is the Philippine "War on Drugs" an Act of Genocide? Journal of Genocide Research, 20(1), 68-89. https://doi.org/10.1080/14623528.2017.1379939

Simon, S. W. (2012). Conflict and Diplomacy in the South China Sea. Asian Survey, 52(6), 995-1018. https://doi.org/10.1525/as.2012.52.6.995

Thao, N. H. (2003). The 2002 Declaration on the Conduct of Parties in the South China Sea: A Note. Ocean Development \& International Law, 34(3-4), 279-285. https://doi.org/10.1080/00908320390221849

Yu, M. (2016). The South China Sea dispute and the Philippines Arbitration Tribunal: China's Policy Options. Australian Journal of International Affairs, 70(3), 215-234. https://doi.org/10.1080/10357718.2015.1135869

Zero Hedge. (2016). A World Preparing for Conflict: Global Military Spending Rises for the First Time in Five Years. Retrieved from: https://www.zerohedge.com/news/2016-04-06/world-preparing-conflict-global-militaryspending-rises-first-time-five-years 